DOI: https://doi.org/10.18371/fp.2(34).2019.184110

УДК 378.14.(004.05)

\title{
ПРОБЛЕМНІ АСПЕКТИ ФОРМУВАННЯ КОМПЕТЕНЦІЙ В СФЕРІ ІНФОРМАЦІЙНОЇ БЕЗПЕКИ МАЙБУТНІХ ФАХІВЦІВ ЕКОНОМІЧНОГО ПРОФІЛЮ
}

\author{
КАСЯРУМ Ярослав Олегович \\ кандидат педагогічних наук, доиент \\ Черкаського інституту ДВНЗ «Університет банківської справи» \\ ORCID ID: http://orcid.org/0000-0002-3783-7520 \\ e-mail: kasyayar@gmail.com
}

\begin{abstract}
Анотація. $У$ статті виявлено особливості корпоративної інформації, сформульовано вимоги дотримання правил інформачійної безпеки та проведено оцінку готовності майбутніх фахівиів економічного профілю до компетентної роботи в корпоративних системах захисту інформаиії.

Ключові слова: інформачійна безпека, захист інформації, корпоративні системи захисту інформації, безпека інформачійних систем.
\end{abstract}

Постановка проблеми. В умовах глобалізації економічних процесів, розширення зв'язків між країнами, пошуків нових ринків збуту продукції та боротьби за них посилилась актуальність дотримання вимог інформаційної безпеки суб'єктами економічних відносин. Це є зрозумілим, оскільки саме вони є власниками корпоративної інформації, яка містить важливі відомості стосовно стану економічної діяльності підприємства, установи або фірми, перспектив їх розвитку, планів розширення або згортання випуску продукції, прибутків, ресурсів тощо. Незалежно від форми власності і профілю діяльності кожна установа праг-
Аннотация. В статье выявлены особенности корпоративной информачии, сформулированы требования соблюдения правил информационной безопасности и проведена оценка готовности будущих специалистов экономического профиля до компетентной работы в корпоративных системах защиты информачии.

Ключевые слова: информационная безопасность, защита информации, корпоративные системы защитты информации, безопасность информационных систем.

не надійно зберігати корпоративну інформацію, особливо фінансову, яка все частіше стає об'єктом противоправних дій, вкладаючи для цього кошти в технічне обладнання та відповідну кваліфікацію співробітників. Між тим, розвиток систем захисту інформації відбувається настільки швидко, що Держспоживстандарт України вимушений постійно оновлювати національний стандарт України в цій галузі. Якщо попередній стандарт щодо методів захисту та об'єктів захисту інформації для керування доступом був прийнятий у 2006 р. [1], то останній стандарт - у 2010 р. [2]. Ця обставина підкреслює актуальність обраної про- 
блематики і спонукає прискіпливо підходити до підготовки майбутніх фахівців економічного профілю в питаннях формування компетенцій в сфері захисту інформації.

Аналіз наукових досліджень. Проблема безпеки інформаційних систем, які зберігають і захищають корпоративну інформацію, є однією з актуальних проблем сьогодення, на що вказують А. В. Абрамов, Ю. В. Гайкович, Дж. Джонсон, В. А. Крисін, Г. Мур, А. С. Першин та інші. Варто підкреслити, що проблема захисту інформації викликає інтерес у науковців різних галузей наук: філософії (В. О. Ананьїн), філології, зокрема, структурносемантична характеристика термінології програмування, комп'ютерних мереж та захисту інформації (А. О. Ніколаєва), права (М. Антонович, А. В. Пазюк, А. І. Марущак, О. В. Шепета, В. С. Дергачов, О. О. Лисенко, І. С. Оверченко). Останнім часом нею зацікавились і психологи, оскільки актуалізувалось питання надання необхідної психологічної допомоги під час відбору персоналу, в першу чергу, для фінансово-кредитних установ. Водночас, зауважимо, що зазначеною проблемою переважно займаються фахівці в галузі фізикоматематичних (І. Ю. Іванов, Д. О. Лу к'янов та ін.) і технічних наук (В. Г. Бабенко, Л. О. Забродська, М. В. Захарченко, Є. А. Золотавкін, О. А. Зюзя, В. С. Климнюк, А. А. Кобо зєва, М. Г. Коляда, А. В. Петрашенко, Л. В. Пономаренко, Б. П. Томашевський, Г. О. Торба, В.В.Шорошев та ін.), дослідження яких призначені для службового користування, адже містять технічні розробки систем захисту інформації. Аналіз наукового доробку в галузі педагогічних наук виявив, що проблемою підготовки фахівців у сфеpi захисту інформації займалися: Г. П. Чуприна [3] - методика навчання програмних засобів захисту інформації майбутніх інженерів-педагогів на основі викладання дисципліни «Програмні засоби захисту інформації»; О. С. Щербій [4] - педагогічні умови формування морально-психологічної готовності курсантів спеціалізованих закладів освіти до професійної діяльності в службі захисту інформації; М. М. Браіловський [5], О.О.Кузнецов [6], Л. В. Чижевська [7] - частково розглядають проблему захисту інформації систем 3 метою забезпечення економічної безпеки підприємства. Поряд 3 цим, проблема формування компетенцій забезпечення інформаційної безпеки в процесі підготовки фахівців економічного профілю не порушувалась.

Важливість цього питання визначається тим, що будь-який фахівець економічного профілю, здійснюючи свої професійні обов'язки, вимушений працювати в корпоративній системі захисту інформації та дотримуватись інструкції щодо збереження корпоративної інформації. Між тим, практика свідчить про те, що фахівець може: 1) несвідомо ставитися до корпоративної інформації і розголошувати іiі зміст; 2) виявляти безвідповідальність, втрачаючи оперативну інформацію або не забезпечуючи іiі збереження, а також ключі та коди доступу; 3) здатний виявляти слабкість щодо примарних перспектив збагачення шляхом присвоєння чужих грошей. Дослідження Datapro Information Services 
Group виявило, що більшість порушень $(81,7 \%)$ здійснюються службовцями організації, які мають доступ до iii системи і лише $17,3 \%$ порушень сторонніми особами [8, с. 101]. Отже, проблема готовності фахівців економічного профілю до забезпечення вимог інформаційної безпеки в корпоративних інформаційних системах $€$ й досі невирішеною та актуальною.

Мета статті полягає у дослідженні змісту стандартів вищої освіти стосовно забезпечення формування компетенцій в сфері інформаційної безпеки при реалізації освітніх програм підготовки фахівців економічного профілю.

Виклад основного матеріалу. Різноманітні корпоративні інформаційні системи у тому числі оперують масивами закритої інформації, яка набуває специфічного змісту, що відтворює напрями економічної діяльності суб'єкта господарювання або установи i тому потребує захисту. Зважаючи на це, оцінку змісту корпоративної інформації стосовно вразливості і потенційного інтересу до неї сторонніх осіб можна визначити або спираючись на основі положення Закону України «Про збереження інформації», або аналізуючи види економічних злочинів, оскільки вони пов'язані або $є$ свідченням порушення систем захисту корпоративної інформації. За ступенем злочинної активності найбільшої уваги потребують кредитні, обліковорозрахункові, валютні та фондові операцій. Останнім часом бачимо, що перелік таких операцій розширяється, а самі вони набувають нових ознак i особливостей у зв'язку з динамічним поширенням інформаційно-обчислювальних і платіжних систем, техноло- гій дистанційного надання фінансових послуг, електронних бірж, електронної комерції та інтернету-речей. Це, в свою чергу, формує нові вимоги до систем інформаційної безпеки.

Зауважимо, що вже на початку 60-х pp. ХХ ст. У правових документах 3 проблеми інформаційної безпеки 3'явився новий термін «комп'ютерна злочинність». Якщо експертна група у Парижі в 1983 р. визначила його сутність як будь-яку незаконну, неетичну або недозволену поведінку, що зачіпає автоматизовану обробку даних і (або) передачу даних, то зараз комп'ютерна злочинність охоплює злочини, які здійснюються за допомогою комп'ютерів, інформаційно-обчислювальних систем і засобів телекомунікацій, або спрямовані проти них 3 корисливою або іншою метою. Е. Сазерленд, фахівець у галузі проблем економічної злочинності та кримінолог, наголошуючи на важливості підготовки співробітників фінансових установ до виконання вимог інформаційної безпеки, навіть увів до наукового обігу термін «білокомірцева злочинність». Послуговуючись результатами досліджень Datapro Information Services Group [8, c.101], наголосимо, що з'ясування мотивів вчинків-порушень вимог системи захисту інформації службовцями організацій виявило, що 10\% 3 них вчинені скривдженими і незадоволеними службовцями-користувачами корпоративної системи захисту інформації, приблизно 10\% - персоналом 3 корисливих мотивів, але більшість (50-55\%) є результатом ненавмисних помилок, наслідком недбалості, безвідповідальності або некомпетентності персоналу i/aбо користувачів системи. 
Ця цифра є достатньо значною, щоб не приймати їі до уваги. Крім того, особливу увагу привернули 50-55\% порушень, що відбуваються внаслідок недбалості, безвідповідальності або некомпетентності фахівців, що, в свою чергу, поставило запитання стосовно виявлення характеру цих порушень та причин некомпетентності службовців як користувачів корпоративної системи захисту інформації.

Так, опитування здобувачів щодо важливості і значення формування готовності до роботи в корпоративних системах захисту інформації показало, що вони не повною мірою усвідомлюють значущість існуючої проблеми. Зокрема, 72,8 \% респондентів стверджують, що захист інформації $\epsilon$ завданням не їх, як майбутнього службовця, а завданням певного підрозділу організації, тобто фахівців-інженерів, що обслуговують систему захисту, вони не вбачають власної причетності до збереження корпоративної інформації. На запитання «Чи можете Ви вільно використовувати закриту інформацію установи в середовищі своїх друзів?» 28,3\% опитаних відповіли ствердно, що свідчить про неусвідомлення ними сутності закритої корпоративної інформації. На запитання «Як відомо, керівники корпорації мають найвищий рівень доступу до секретної інформації, а службовці залежно від рангу та посади мають менший рівень доступу до неї. Хто, на Вашу думку, наносить більшу шкоду інтересам корпорації?» 82,9\% опитуваних вважають, що керівники, маючи можливість користування секретною інформацією, наносять найбільшу шкоду. Але це не підтверджується ре- зультатами досліджень, бо такі випадки виключні й поодинокі, а найбільшу шкоду наносять саме керівники середньої ланки та службовці. Отже, здобувачі, як майбутні фахівці, не усвідомлюють важливості і необхідності захисту інформації в повсякденній професійній діяльності, мають невисокий рівень готовності до роботи в корпоративних системах захисту інформації.

На нашу думку, причина цього полягає, у тому числі, в планах і програмах професійно-орієнтованої підготовки фахівців. На сьогодні поглиблюються процеси реформування та інституційної трансформації вищої освіти, де якість освіти визначається одним 3 основних пріоритетів, передумови якої поряд 3 матеріальнотехнічним забезпеченням і кадровим потенціалом створюють змістовно професійно-орієнтовані та інноваційні освітні програми. Дійсно, останнім часом заклади вищої освіти набули універсальності, 3 погляду на перелік спеціальності та освітніх програм підготовки фахівців, але, водночас, втратили власну індивідуальність (унікальність), яку підкреслювала (посилювала) їх профільність. Так, отримали ліцензії та здійснюють підготовку майбутніх економістів аграрні, технічні, педагогічні, лінгвістичні, екологічні, військові, технологічні, гуманітарні, медичні, юридичні університети, а також транспорту, будівництва та архітектури, культури, славістики та інші (рис. 1). Бачимо, що на класичні та економічні університети припадає лише 29,35\% ринку освітніх послуг підготовки фахівців економічного профілю, а його більша частка припа- 
дає на непрофільні заклади освіти вищих навчальних, де здійснюють підготовку фахівців переважно зі спеціаль-

Компаративний аналіз Стандартів вищої освіти першого (бакалаврського) рівня вищої освіти (табл. 1) показав розуміння необхідності використання сучасні інформаційні системи $\mathrm{i}$ комп'ютерні технології, спеціальних ностей «Фінанси, банківська справа та страхування» та «Облік і оподаткування».

пакетів прикладних програм, інформаційно-аналітичні системи, як основних інструментів вирішення завдань професійної діяльності та обов'язкових для підготовки фахівців економічного профілю.

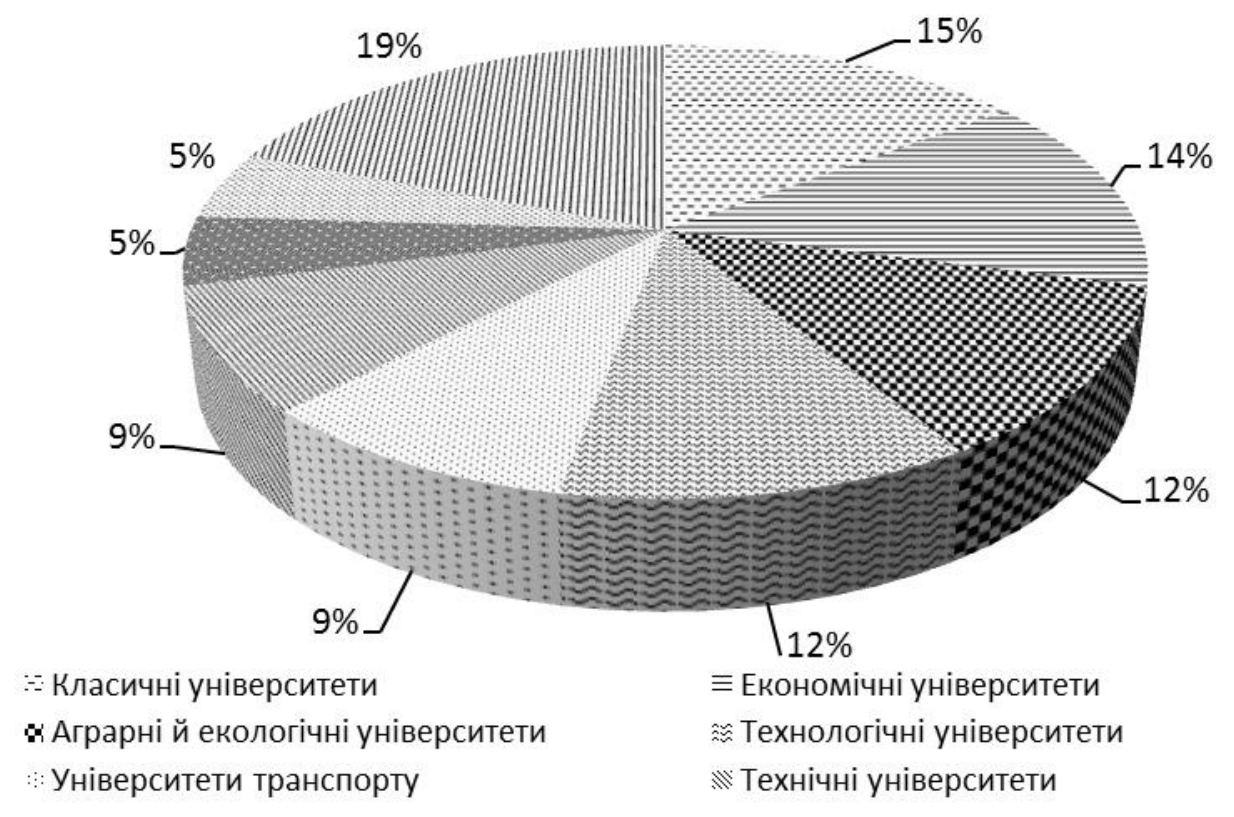

Рис. 1 Розподіл вищих навчальних закладів, які за ліцензією здійснюють підготовку майбутніх економістів

Поряд $з$ цим спостерігаємо відсутність формулювання та включення до загальних та/або спеціальних компетенцій в сфері інформаційної безпеки.

На нашу думку, сутність компетенції в сфері інформаційної безпеки полягає в професійній характеристиці фахівців економічного профілю, а іiі зміст формують: знань щодо місця і ролі інформаційної безпеки, правових засад, принципів і методів організації захисту корпоративної інформації, а також протидії проявам несанкціонованого інформаційного впливу та витоку інформації, враховуючи поведін- кові аспекти персоналу; вмінь формулювати і реалізовувати політику, аналізувати і оцінювати загрози та здійснювати заходи протидії порушенням інформаційної безпеки в конкретній професійній сфері діяльності; навичок аналізу і формалізації інформаційних процесів, формування вимог до систем захисту інформації.

Набуття компетенції в сфері інформаційної безпеки фахівців економічного профілю може бути вирішено шляхом включенням нових навчальних дисциплін до освітніх програм або в блоці дисциплін загальної підготов- 
ки, або вибіркових фахових дисциплін. Також, доцільним $\epsilon$ включення окремих тем щодо забезпечення без- пеки економічної інформації до тематичного плану фахових дисциплін спеціальностей.

Таблиця 1

Компаративний аналіз Стандартів вищої освіти першого (бакалаврського) рівня вищої освіти в контексті формування компетенцій в сфері інформаційної

\begin{tabular}{|c|c|}
\hline Компетенції & Зміст \\
\hline \multicolumn{2}{|c|}{$\begin{array}{c}\text { Стандарт вищої освіти за спеціальністю «Фінанси, банківська справа та страхування" } \\
\text { для перщого (бакалаврського) рівня вищої освіти (наказ МОН Украйни № 729від } \\
25.05 .2019) \\
\end{array}$} \\
\hline $\begin{array}{l}\text { Опис предметної області / Ін- } \\
\text { струменти та обладнання }\end{array}$ & сучасні інформаційно-аналітичні системи \\
\hline Загальні компетентності & $\begin{array}{l}\text { ЗК05. Навички використання інформаційних та комуні- } \\
\text { каційних технологій } \\
\text { ЗК08. Здатність до пошуку, оброблення та аналізу інфо- } \\
\text { рмації з різних джерел }\end{array}$ \\
\hline $\begin{array}{l}\text { Спеціальні (фахові, предметні) } \\
\text { компетентності }\end{array}$ & $\begin{array}{l}\text { СК06. Здатність застосовувати сучасне інформаційне та } \\
\text { програмне забезпечення для отримання та обробки да- } \\
\text { них у сфері фінансів, банківської справи та страхування }\end{array}$ \\
\hline $\begin{array}{l}\text { Нормативний зміст підготовки } \\
\text { здобувачів вищої освіти (резуль- } \\
\text { тати навчання }\end{array}$ & $\begin{array}{l}\text { ПР08. Застосовувати спеціалізовані інформаційні систе- } \\
\text { ми, сучасні фінансові технології та програмні продукти }\end{array}$ \\
\hline \multicolumn{2}{|c|}{$\begin{array}{c}\text { Стандарт вищої освіти за спеціальністю «Облік і оподаткування» для периого (бака- } \\
\text { лаврського) рівня вищої освіти (наказ МОН України № } 1260 \text { від 19.11.2018) }\end{array}$} \\
\hline $\begin{array}{l}\text { Опис предметної області / Ін- } \\
\text { струменти та обладнання }\end{array}$ & $\begin{array}{l}\text { сучасні інформаційні системи і комп’ютерні технології, } \\
\text { стандартні, спеціальні й галузеві пакети прикладних } \\
\text { програм обліку, аналізу, контролю, аудиту, оподатку- } \\
\text { вання }\end{array}$ \\
\hline Загальні компетентності & $\begin{array}{l}\text { ЗК11. Навички використання сучасних інформаційних } \\
\text { систем і комунікаційних технологій. }\end{array}$ \\
\hline $\begin{array}{l}\text { Спеціальні (фахові, предметні) } \\
\text { компетентності }\end{array}$ & $\begin{array}{l}\text { СК06. Здійснювати облікові процедури із застосуванням } \\
\text { спеціалізованих інформаційних систем і комп’ютерних } \\
\text { технологій }\end{array}$ \\
\hline $\begin{array}{l}\text { Нормативний зміст підготовки } \\
\text { здобувачів вищої освіти (резуль- } \\
\text { тати навчання }\end{array}$ & $\begin{array}{l}\text { ПР12. Застосовувати спеціалізовані інформаційні систе- } \\
\text { ми і комп’ютерні технології для обліку, аналізу, контро- } \\
\text { лю, аудиту та оподаткування }\end{array}$ \\
\hline \multicolumn{2}{|c|}{$\begin{array}{c}\text { Стандарт вищеої освіти за спеціальністо «Економіка» для периого (бакалаврського) } \\
\text { рівня вищої освіти (наказ МОН Украӥни №1260 від 19.11.2018) }\end{array}$} \\
\hline $\begin{array}{l}\text { Опис предметної області / Iн- } \\
\text { струменти та обладнання }\end{array}$ & $\begin{array}{l}\text { сучасне інформаційно-комунікаційне обладнання, інфо- } \\
\text { рмаційні системи та програмні продукти, що застосову- } \\
\text { ються у професійній діяльності. }\end{array}$ \\
\hline Загальні компетентності & $\begin{array}{l}\text { ЗК7. Навички використання інформаційних і комуніка- } \\
\text { ційних технологій }\end{array}$ \\
\hline $\begin{array}{l}\text { Спеціальні (фахові, предметні) } \\
\text { компетентності }\end{array}$ & $\begin{array}{l}\text { СК7. Здатність застосовувати комп'ютерні технології та } \\
\text { програмне забезпечення з обробки даних для вирішення } \\
\text { економічних завдань, аналізу інформації та підготовки } \\
\text { аналітичних звітів }\end{array}$ \\
\hline
\end{tabular}


Закінчення табл.1

\begin{tabular}{|c|c|}
\hline Компетенції & Зміст \\
\hline $\begin{array}{l}\text { Нормативний зміст підготовки здо- } \\
\text { бувачів вищої освіти (результати } \\
\text { навчання }\end{array}$ & $\begin{array}{l}\text { ПР19. Використовувати інформаційні та комуніка- } \\
\text { ційні технології для вирішення соціально- } \\
\text { економічних завдань, підготовки та представлення } \\
\text { аналітичних звітів }\end{array}$ \\
\hline \multicolumn{2}{|c|}{$\begin{array}{c}\text { Стандарт вищої освіти за спеціальністю «Менеджсмент» для перщого (бакалаврсько- } \\
\text { го) рівня вищцї освіти (наказ МОН Украӥни № } 1165 \text { від 29.10.2018) }\end{array}$} \\
\hline $\begin{array}{l}\text { Опис предметної області / Інструме- } \\
\text { нти та обладнання }\end{array}$ & $\begin{array}{l}\text { сучасне інформаційно-комунікаційне обладнання, } \\
\text { інформаційні системи та програмні продукти, що } \\
\text { застосовуються в менеджменті. }\end{array}$ \\
\hline Загальні компетентності & 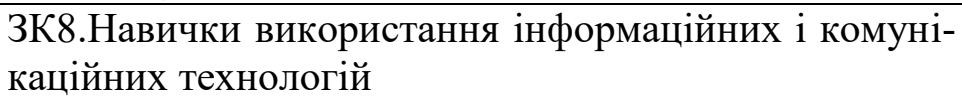 \\
\hline $\begin{array}{l}\text { Спеціальні (фахові, предметні) ком- } \\
\text { петентності }\end{array}$ & відсутні \\
\hline $\begin{array}{l}\text { Нормативний зміст підготовки здо- } \\
\text { бувачів вищої освіти (результати } \\
\text { навчання }\end{array}$ & відсутні \\
\hline
\end{tabular}

Джерело: побудовано автором на основі зазначених вище Стандартів вищої освіти

Висновки. Отже, недостатній рі- цифровізації в усі сфери життедіяльвень готовності фахівців економічного ності. На наше переконання, в цьому профілю до роботи в корпоративних аспекті перелік компетенцій необхідно системах захисту інформації зумовле- розширити, включивши для майбутніх ний відсутністю уваги в стандартах фахівців економічних спеціальностей вищої освіти та освітніх програмах до обов'язковість набуття знань, навичок формування компетенцій в сфері захи- та вмінь щодо інформаційної безпеки сту інформації, які набувають актуа- як важливої складової фінансової та льності в умовах формування інфор- економічної безпеки загалом. маційного суспільства та поширення

\section{Список використаної літератури}

1. Системи оброблення інформації; Взаємоз'вязок відкритих систем. Базова еталонна модель. Національний стандарт України. Ч. 2 : ДСТУ ISO 74982:2004; Архітектура захисту інформації (ISO 7498-2:1989, IDT) / пер. і наук.техн. ред. А. Гладун [та ін.]. [Чинний від 01.04.2006]. К. : Держспоживстандарт України [Б. м.] : [б.в.]. 2006. 40 с.

2. Інформаційні технології. Методи захисту, об'єкти захисту інформації для керування доступом (ISO/IEC 15816:2002, IDT). Національний стандарт України. [Чинний від 2010-01-01]. К: Держспоживстандарт України, 2010. IV. 20 с.. 
3. Чуприна Г. П. Методика навчання програмних засобів захисту інформації майбутніх інженерів-педагогів: автореф. дис. на здобуття наук. ступеня канд. пед. наук : спец. 13.00.02. Укр. інж.-пед. акад. Х. 2010. 20 с.

4. Щербій О. С. Педагогічні умови формування морально-психологічної готовності курсантів спеціалізованих ВНЗ до професійної діяльності : [монографія]. К. : Три К. 2011. 254 с.

5. Браіловський М. М. Захист інформації у банківській діяльності. К. : ПВП «Задруга». 2003. 158 с.

6. Кузнецов О. О. Захист інформації та економічна безпека підприємства: монографія. Х. : ХНЕУ. 2008. 360 с.

7. Чижевська Л. В. Професійна діяльність бухгалтера: аутсорсинг, ризики, захист інформації: монографія. Житомир : ЖДТУ. 2011. 403 с.

8. Гайкович Ю. В., Першин А. С. Безопасность электронных банковских систем. М.: Единая Европа. 1994. 126 с. 